\title{
Comparison of The Effects of Dietary Supplementation of Natural Antimicrobial Feed Additives on Lipid Oxidation, Microbial Content and Quality of Broiler Raw Meat
}

\author{
Senay Sarica ${ }^{*}$, Dursen Urkmez ${ }^{2}$ \\ ${ }^{1}$ Department of Animal Science, Faculty of Agriculture, Tokat Gaziosmanpasa University, 60240 Tasliciftlik/Tokat, Turkey \\ ${ }^{2}$ Tokat Directorate of Provincial Agriculture and Forestry, 60200 Tokat, Turkey
}

\begin{tabular}{l}
\hline A R T I C L E I N F O \\
Research Article \\
Received 03 January 2018 \\
Accepted 04 September 2018 \\
\hline
\end{tabular}

Keywords:

Broiler

Natural antimicrobials

Lipid oxidation

Microbial content

Meat quality

*Corresponding Author:

E-mail: senay.sarica@gop.edu.tr \begin{abstract}
A B S T R A C T
The study aimed to compare the effects of dietary supplementation of probiotic and olive leaf-, grape seed- and pomegranate peel extracts as natural antimicrobial on lipid oxidation, microbiological content and quality of raw broiler meat. Chickens were fed the control diet (CONT) and diets supplemented with probiotic (P), oleuropein (olive leaf extract, OLE100 and OLE200), proanthocyanidin (grape seed extract, GSE100 and GSE200) and proanthocyanidin (pomegranate peel extract, PPE100 and PPE200) at 100 and $200 \mathrm{mg} / \mathrm{kg}$ levels to the CONT diet. All dietary treatments significantly reduced MDA value of breast meat at $9^{\text {th }}$ day, total aerobe bacteria and coliform bacteria contents of breast meat at $14^{\text {th }}$ day. The P, OLE200, PPE100 and PPE200 diets significantly decreased lactic acid bacteria content of breast meat at $14^{\text {th }}$ day. The $\mathrm{pH}$ value of raw breast meat at $24 \mathrm{~h}$ was significantly reduced by dietary treatments compared to the CONT diet. Feeding the P, PPE100 and PPE200 diets significantly increased water holding capacity of breast meat compared to those of broilers fed the CONT, GSE100 and GSE200 diets. The P, OLE200, PPE100 and PPE200 diets significantly reduced drip loss of breast meat at $7^{\text {th }}$ day compared to the CONT, OLE100, GSE100 and GSE200 diets. Cooking loss of breast meat was significantly decreased by all dietary treatments except GSE diet compared to the CONT diet. It was concluded that probiotic, olive leafand pomegranate peel- extracts have potential to be used as natural antimicrobial feed additives in terms of the lipid oxidation, microbial content and quality of broiler meat.
\end{abstract}

DOI: https://doi.org/10.24925/turjaf.v6i11.1537-1543.1782

\section{Introduction}

Chicken meat is a preferred valuable source of animal protein by consumers worldwide due to its low price and desirable nutrient profile that has low fat and relatively high polyunsaturated fatty acids (Zhang et al., 2016; Saleh et al., 2017). Fresh meat and meat products are generally stored in refrigerator at $+2-4^{\circ} \mathrm{C}$ until marketing. Microbial growth and lipid oxidation occurred during refrigeration storage negatively influenced the shelf-life, sensory, nutritional qualities and consumer acceptance of fresh meat and meat products (Hayes et al., 2010; Kaur et al., 2015). To inhibit the above mentioned negatives on meat and meat products, the use of by products of fruit juice industry and probiotic as natural antimicrobial feed additives in broiler diets due to the health risks of their synthetic forms came into prominence (Kaur et al., 2015).

Waste products like peel, seed and leaf fractions of some fruits like pomegranate, grape and olive have higher antimicrobial activity than their pulp fractions (Kaur et al., 2015). There are limited literature related to the comparison of the effects of pomegranate peel-, grape seed- and olive leaf-extracts on the broiler meat and meat products.

Pomegranate peel constituted approximately $50 \%$ of the whole fruit and is an inedible by-product obtained during processing to pomegranate juice (Turgut et al., 2017; Saleh et al., 2017). Pomegranate peel and its extract are a major source of flavonoids, condensed- and hydrolysable- tannins (Ahmed et al., 2015). Grape seed is a by-product of wine and grape juice processing enriched in proanthocyanidins (condensed tannins) (Mielnik et al., 2006; Brannan, 2009). The olive leaf is an agricultural waste of olive oil processing rich in oleuropein and hydroxytyrosol (Benavente- Garcia et al., 2000).

There are some studies demonstrating the effects of pomegranate peel extract (Kanatt et al., 2010), grape seed extract (Kaur et al., 2015) and olive leaves and their 
extracts (Marangoni et al., 2017) as antimicrobial feed additives due their polyphenolic compounds on chicken meat quality.

Probiotics defined as viable microorganisms are used as an alternative to antibiotic growth promoters in poultry industry. There are some literature associated with the preventing effect of dietary probiotic on the microbial contamination of meat due to its antimicrobial property (Khaksefidi and Rahimi, 2005). Some studies pointed out that the probiotic supplementation to chicken diet improves the sensory and nutritional qualities, lipid oxidation stability and microbial safety of chicken meat (Kim et al., 2016; Abdulla et al., 2017).

The present study aimed to compare the effects of probiotic and fruit industry residue extracts as natural antimicrobial feed additives on lipid oxidation, microbial content and quality of broiler raw meat.

\section{Materials and Methods}

\section{Ethical Note}

This study was conducted following the animal ethics guidelines of the Research Policy of Gaziosmanpaşa University.

\section{Birds and Housing}

A total of five hundred seventy-six one-d-old Ross 308 male broiler chicks were randomly assigned to 8 groups, each of which was replicated 3 times with 24 broiler chicks per replicate. All chicks were housed on litter in a floor system with the controlled temperature and humidity. Each pen was provided with a single feeder and automatic nipple drinkers. A $23 \mathrm{~h}$ light and $1 \mathrm{~h}$ dark lighting program was applied during the experiment. The diets in mash form and drinking water were provided $a d$ libitum.

\section{Diets}

Prior to experimental diet formulation, feed ingredients were analysed for their crude protein (CP), ether extract, starch and total sugar according to the methods of the AOAC (2007). All diets were formulated to meet minimum nutrient requirements established by nutrition specifications for Ross 308. The diets per treatment were formulated to cover all the fattening period (starter, grower and finisher). The starter diet (23\% $\mathrm{CP}$ and $3.025 \mathrm{Kcal} / \mathrm{kg} \mathrm{ME}$ ) from 0 to $10 \mathrm{~d}$, the grower diet $(22 \% \mathrm{CP}$ and $3.150 \mathrm{Kcal} / \mathrm{kg} \mathrm{ME})$ from 11 to $28 \mathrm{~d}$ and the finisher diet (19\% CP and $3200 \mathrm{Kcal} / \mathrm{kg} \mathrm{ME}$ ) from 29 to $42 \mathrm{~d}$ were provided for broilers during the experiment. The experimental diets included an feed additives-free basal diet (CONT) and the other diets supplemented with probiotic (P) (Protexin ${ }^{\mathrm{TM}} ; 1.5,1.0$ and $0.5 \mathrm{~kg} /$ tonne for the starter, grower and finisher diets, respectively), oleuropein (olive leaf extract: OLE), proanthocyanidin (grape seed extract: GSE) and proanthocyanidin (pomegranate peel extract: PPE) at the levels of 100 and $200 \mathrm{mg} / \mathrm{kg}$ to the CONT diet. With attention of oleuropein content of OLE and proanthocyanidin contents of GSE and PPE, OLE, GSE and PPE were supplemented by providing oleuropein and proanthocyanidin levels at 100 and $200 \mathrm{mg} / \mathrm{kg}$ diet.

\section{Olive Leaf Extract}

To obtain the olive leaf extract, the olive leaves were collected from olea europaea L. trees cultivated under organic farming practices in Ayvalik. Collected leaves were firstly dried in air-oven at $30^{\circ} \mathrm{C}$ for $24 \mathrm{~h}$ and then ground to pass $2 \mathrm{~mm}$ screen. A $10 \mathrm{~g}$ of olive leaves powder was extracted for $24 \mathrm{~h}$ with $100 \mathrm{ml}$ of $70 \%(\mathrm{v} / \mathrm{v})$ aqueous ethanol at room temperature by a shaking incubator at $180 \mathrm{rpm}$. The extracts were filtered with Whatman No.1 filter paper. The filtrates were transferred to a rotary evaporator to remove ethanol under reduced pressure at $38^{\circ} \mathrm{C}, 120 \mathrm{rpm}$. The remaining aqueous solutions were lyophilized at $-50^{\circ} \mathrm{C}, 0.028 \mathrm{mbar}$ and the crude extracts were kept in vacuum bags at $-80^{\circ} \mathrm{C}$ until the use.

\section{Grape Seed Extract}

The Horoz Karas1 grape seeds (Vitis vinifera L.) were supplied from a local juice processing industry (Dimes Ltd. Company, Tokat, Turkey) and collected first air-oven dried at $70^{\circ} \mathrm{C}$ for $24 \mathrm{~h}$. Dried grape seeds were ground to pass $2 \mathrm{~mm}$ screen and extracted in a Soxhlet extractor with petroleum ether $\left(60-80^{\circ} \mathrm{C}\right.$ for $\left.6 \mathrm{~h}\right)$ to extract the fatty material. The defatted grape seed powder (100 g) was extracted in a back cooler on the jacket heater for $8 \mathrm{~h}$ separately with $150 \mathrm{ml}$ of acetone:water:acetic acid (90:9.5:0.5). The extracts were handled further according to the procedure for olive leaf extract.

\section{Pomegranate Peel Extract}

Pomegranate fruits (Punica granatum L., Hicaznar) were supplied from the Agricultural Research Institute of West Mediterranean (Antalya, Turkey). The fresh fruits were manually peeled and cut using a shear and frezedried. Dried peels were powdered to get 60-mesh size using a mixing grander. For obtaining the pomegranate peel extract, the fine powdered sample (10 g) was extracted three times with $10 \mathrm{ml} 70 \%$ ethanol in water at room temperature $\left(\sim 25^{\circ} \mathrm{C}\right)$ for $4 \mathrm{~h}$ in a magnetic shaker. The extracts were handled further according to the procedure for olive leaf extract.

\section{Analysis of Oleuropein of OLE and Proanthocyanidin} Contents of GSE and PPE

The oleuropein content of OLE and diets was analyzed by a HPLC method of Baycin et al., (2007) in the Sciences of Izmir Institute of Technology (Izmir, Turkey). The proanthocyanidin content of GSE and PPE was determined by the Acid Butanol assay according to the method of Bate-Smith (1975).

\section{Determination of Lipid Oxidation of Meat}

On d 42, 16 birds whose BWs were similar to the group average were selected from each treatment group. A total of 128 broilers were slaughtered by severing the jugular vein to determine the lipid oxidation of meat. Lipid oxidation was determined according to the method of Botsoglou et al. (2002). In brief, $2 \mathrm{~g}$ of samples were thoroughly homogenized with aqueous trichloroacetic acid $(8 \mathrm{ml}, 5 \%)$ and butylated hydroxytoluene in hexane ( $5 \mathrm{ml}, 0.8 \%$ ), and the mixture was centrifuged. A $2.5-\mathrm{ml}$ aliquot from the bottom layer was mixed with $1.5 \mathrm{ml}$ of $0.8 \%$ aqueous 2-thiobarbituric acid to be further incubated at $70^{\circ} \mathrm{C}$ for $30 \mathrm{~min}$. Following incubation, the mixture 
was submitted to conventional spectrophotometry (Shimadzu, Model UV-1601, Tokyo, Japan) in the range of $530 \mathrm{~nm}$. Third-order derivative spectra was produced by digital differentiation of the normal spectra using a derivative wavelength difference setting of $21 \mathrm{~nm}$. The concentration of MDA (ng/g wet tissue) in analysed extracts was calculated on the basis of the height of the third-order derivative peak at $521.5 \mathrm{~nm}$ by referring to slope and intercept data of the computed least-squares fit of standard calibration curve prepared using 1,1,3,3tetraethoxypropane

\section{Microbial Analysis of Meat}

One half of the breast meat of a total of 128 chickens slaughtered was packaged in a vacuum polyamide ethylene-vinylacetate/polyethylene bag. Vacuum packaged breasts were stored at $+4^{\circ} \mathrm{C}$ for 14 days in refrigerator. The microbiological analyses of the breast meat samples for $0^{\text {th }}, 7^{\text {th }}$ and $14^{\text {th }}$ days were determined according to the methods of Baumgart et al. (1993). For this analysis, breast meat samples $(25 \mathrm{~g})$ were homogenized with $225 \mathrm{ml}$ of physiological saline water $(0.85 \% \mathrm{NaCl})$ in a homogenizer for $1 \mathrm{~min}$. Total aerobic bacteria was enumerated on Plate Count Agar at $30^{\circ} \mathrm{C}$ for 24 h. Coliform bacteria and Lactic acid bacteria, respectively, were enumerated on Plate Violet red bile agar and de Man Rogosa Sharpe Agar (MRS), respectively, at $37^{\circ} \mathrm{C}$ for $48 \mathrm{~h}$.

\section{Meat Quality Parameters}

A total of 128 chickens slaughtered were used to determine the quality parameters $(\mathrm{pH}$, water holding capacity, drip loss, cooking loss) of breast meat. The carcasses were vacuum packed and stored in a deep freezer at $-80^{\circ} \mathrm{C}$ until required for analysis. The frozen carcasses were thawed in a refrigerated condition $\left(+4^{\circ} \mathrm{C}\right)$ and breast fillets were dissected.

\section{$p H$}

The upper one-third from the right side of the breast meat was used for $\mathrm{pH}$ measurement. The $\mathrm{pH}$ values were determined for 15 min post slaughter (initial $\mathrm{pH}, \mathrm{pHi}$ ) and after chilling for $24 \mathrm{~h}$ at $+4^{\circ} \mathrm{C}$ in self-sealed plastic bags, using a portable $\mathrm{pH}$ meter (Testo 205) equipped with a stainless electrode (pH57-SS) (Lu et al., 2007).

\section{Water Holding Capacity}

The water holding capacity (WHC) of breast meat was estimated (Castellini et al., 2002) by centrifuging $1 \mathrm{~g}$ of the meat, placed on tissue paper inside a tube for $4 \mathrm{~min}$ at $1500 \times \mathrm{g}$. The water remaining after centrifugation was quantified by drying the samples at $70^{\circ} \mathrm{C}$ overnight. WHC was calculated as: (weight after centrifugation-weight after drying)/initial weight $\times 100$.

\section{Drip loss}

The drip loss of each breast meat was measured using the suspension method (Bond and Warner 2007; Chiang et al., 2008). Each meat sample was trimmed to an approximately equal size $(12 \mathrm{~cm} \times 10 \mathrm{~cm})$, weighed, placed in a polyethylene bag and hung at $+4^{\circ} \mathrm{C}$ for $24 \mathrm{~h}$. The meat sample was removed from the bag, blotted dry, and reweighed to determine drip loss. Drip loss was calculated as: (initial weight-final weight)/initial weight $\times$ 100 .

\section{Cooking loss}

The breast meats were weighed before and after cooking to determine percentage of cooking loss. The meat samples (20-25 g) were put in a plastic bag and then cooked for $40 \mathrm{~min}$. in a water bath with constant temperature of $70^{\circ} \mathrm{C}$. After the meat samples were cooled to room temperature $\left(25^{\circ} \mathrm{C}\right)$, removed from the bag and blotted dry. All samples from a given replicate were cooked and chilled as one batch. The cooked breast fillet was reweighed to determine the cook loss (Mitchaothai et al., 2006). Cooking loss was calculated as: (initial weightfinal weight)/initial weight $\times 100$.

\section{Statistical Analysis}

Linear Model using the SPSS (17.0) ${ }^{\circledR}$ statistic package (SPSS, 2007) was applied to data obtained from the experiment. Significant differences between treatment means were separated using Duncan's multiple range test (Duncan, 1955). Results were presented at least square means and standard error of means. All statements of significance were based on $\mathrm{P}<0.05$.

\section{Results and Discussion}

The Oleuropein Content of OLE and The Proanthocyanidin Content of GSE and PPE

The oleuropein content of OLE and the proanthocyanidin content of GSE and PPE and the total phenol contents of OLE, GSE and PPE were given in Table 1 .

\section{Malondialdehyde Value}

The malondialdehyde value of breast meat in broilers fed diet supplemented with probiotic and pomegranate peel-, grape seed- and olive leaf-extracts was given in Table 2.

Table 1 The oleuropein content of OLE and the proanthocyanidin content of GSE and PPE

\begin{tabular}{lcc}
\hline \multicolumn{1}{c}{ Extracts } & PR & OL \\
\hline Grape Seed Extract (GSE) & $6.673 \pm 86$ & - \\
Olive Leaf Extract (OLE) & - & $196.81 \pm 2.83$ \\
Pomegranate Peel Extract (PPE) & $8.420 \pm 2.13$ & - \\
\hline
\end{tabular}

PR: Proanthocyanidin (mg/kg), OL: Oleuropein (mg/g)

As shown in Table 2, there are no any significant differences among dietary treatments in terms of the malondialdehyde value of breast meat at $0^{\text {th }}$ day. The malondialdehyde value of breast meat at $9^{\text {th }}$ day of storage in refrigerator at $+4^{\circ} \mathrm{C}$ was significantly decreased by dietary treatments compared to the CONT diet $(\mathrm{P}<0.001)$. This finding concurs with the results of Saleh et al. (2015, 2017) who reported that dietary pomegranate peel extract significantly delayed the lipid oxidation of broiler meat. Likewise, this result was supported by the finding of Frahat et al. (2016) who pointed out that dietary grape seed extract supplementation led to a significant reduction in the malondialdehyde level in broiler meat. 
Table 2 The malondialdehyde value of breast meat in broilers fed diet supplemented with probiotic and pomegranate peel-, grape seed- and olive leaf-extracts

\begin{tabular}{l|cc}
\hline \multicolumn{1}{c|}{ Dietary Treatments } & $0^{\text {th }} \mathrm{d}$ & $9^{\text {th }} \mathrm{d}$ \\
\hline CONT & 0.173 & $1.918^{\mathrm{a}}$ \\
P & 0.170 & $1.893^{\mathrm{b}}$ \\
OLE100 & 0.163 & $1.633^{\mathrm{d}}$ \\
OLE200 & 0.160 & $1.550^{\mathrm{e}}$ \\
GSE100 & 0.167 & $1.797^{\mathrm{c}}$ \\
GSE200 & 0.163 & $1.667^{\mathrm{d}}$ \\
PPE100 & 0.160 & $1.527^{\mathrm{e}}$ \\
PPE200 & 0.153 & $1.350^{\mathrm{f}}$ \\
Pooled SEM & 0.0028 & 0.0402 \\
P-value & 0.771 & 0.000 \\
\hline
\end{tabular}

${ }^{a-f}$ Column means within the different supercripts do differ (***P<0.001), SEM: Standard Error of Means, CONT: a basal diet which contained no feed additive; P: the diet supplemented with probiotic to the CONT diet; OLE100: the diet supplemented with olive leaf extract at the level of 100 $\mathrm{mg} / \mathrm{kg}$ oleuropein; OLE200: the diet supplemented with olive leaf extract at the level of $200 \mathrm{mg} / \mathrm{kg}$ oleuropein; GSE100: the diet supplemented with grape seed extract at the level of $100 \mathrm{mg} / \mathrm{kg}$ proanthocyanidin; GSE200: the diet supplemented with grape seed extract at the level of $200 \mathrm{mg} / \mathrm{kg}$ proanthocyanidin; PPE100: the diet supplemented with pomegranate peel

Table 3 The microbial content of breast meat in broilers fed diet supplemented with probiotic and pomegranate peel-, grape seed- and olive leaf-extracts

\begin{tabular}{l|ccccccccc}
\hline \multirow{2}{*}{$\begin{array}{c}\text { Dietary } \\
\text { Treatments }\end{array}$} & \multicolumn{3}{c}{ Total aerobe bacteria } & \multicolumn{3}{c}{ Coliform bacteria } & \multicolumn{3}{c}{ Lactic acid bacteria } \\
\cline { 2 - 9 } & $0^{\text {th }} \mathrm{d}$ & $7^{\text {th }} \mathrm{d}$ & $14^{\text {th }} \mathrm{d}$ & $0^{\text {th }} \mathrm{d}$ & $7^{\text {th }} \mathrm{d}$ & $14^{\text {th }} \mathrm{d}$ & $0^{\text {th }} \mathrm{d}$ & $7^{\text {th }} \mathrm{d}$ & $14^{\text {th }} \mathrm{d}$ \\
\hline CONT & $2.893^{\mathrm{a}}$ & $3.783^{\mathrm{a}}$ & $4.590^{\mathrm{a}}$ & 0 & $2.053^{\mathrm{a}}$ & $2.287^{\mathrm{a}}$ & $1.233^{\mathrm{a}}$ & $1.667^{\mathrm{a}}$ & $3.080^{\mathrm{a}}$ \\
P & $2.732^{\mathrm{c}}$ & $3.507^{\mathrm{c}}$ & $4.193^{\mathrm{c}}$ & 0 & $1.393^{\mathrm{f}}$ & $1.523^{\mathrm{f}}$ & $1.123^{\mathrm{c}}$ & $1.413^{\mathrm{c}}$ & $2.927^{\mathrm{b}}$ \\
OLE100 & $2.827^{\mathrm{ab}}$ & $3.743^{\mathrm{a}}$ & $4.373^{\mathrm{b}}$ & 0 & $1.760^{\mathrm{c}}$ & $1.823^{\mathrm{c}}$ & $1.213^{\mathrm{ab}}$ & $1.557^{\mathrm{b}}$ & $3.010^{\mathrm{ab}}$ \\
OLE200 & $2.713^{\mathrm{c}}$ & $3.460^{\mathrm{d}}$ & $4.223^{\mathrm{c}}$ & 0 & $1.660^{\mathrm{d}}$ & $1.773^{\mathrm{d}}$ & $1.190^{\mathrm{b}}$ & $1.533^{\mathrm{b}}$ & $2.960^{\mathrm{c}}$ \\
GSE100 & $2.837^{\mathrm{ab}}$ & $3.737^{\mathrm{a}}$ & $4.443^{\mathrm{b}}$ & 0 & $1.817^{\mathrm{b}}$ & $1.920^{\mathrm{b}}$ & $1.230^{\mathrm{a}}$ & $1.680^{\mathrm{a}}$ & $3.053^{\mathrm{a}}$ \\
GSE200 & $2.807^{\mathrm{ab}}$ & $3.690^{\mathrm{ab}}$ & $4.387^{\mathrm{b}}$ & 0 & $1.720^{\mathrm{c}}$ & $1.837^{\mathrm{c}}$ & $1.227^{\mathrm{a}}$ & $1.667^{\mathrm{a}}$ & $3.000^{\mathrm{ab}}$ \\
PPE100 & $2.613^{\mathrm{d}}$ & $3.430^{\mathrm{d}}$ & $4.167^{\mathrm{c}}$ & 0 & $1.533^{\mathrm{e}}$ & $1.627^{\mathrm{e}}$ & $1.200^{\mathrm{b}}$ & $1.417^{\mathrm{c}}$ & $2.927^{\mathrm{b}}$ \\
PPE200 & $2.373^{\mathrm{e}}$ & $3.197^{\mathrm{e}}$ & $4.077^{\mathrm{d}}$ & 0 & $1.397^{\mathrm{f}}$ & $1.517^{\mathrm{f}}$ & $1.110^{\mathrm{d}}$ & $1.363^{\mathrm{d}}$ & $2.887^{\mathrm{c}}$ \\
Pooled SEM & 0.033 & 0.041 & 0.035 & 0 & 0.044 & 0.050 & 0.010 & 0.026 & 0.014 \\
P-value & 0.000 & 0.000 & 0.000 & 0 & 0.000 & 0.000 & 0.000 & 0.000 & 0.000 \\
\hline
\end{tabular}

${ }^{\mathrm{a}-\mathrm{f}}$ Column means within the different superscripts do differ $(* * * \mathrm{P}<0.001)$; SEM: Standard Error of Means

In addition, Govaris et al. (2010) found that the dietary olive leaves were more effective in preventing of lipid oxidation of turkey breast compared to when the turkeys received no supplementation. This situation may be highly attributed to polyphenolic compounds with the antioxidant activity in OLE, GSE and PPE (Mahmmod, 2014; Farahat et al., 2016; Saleh et al., 2017). The antioxidant activities of these polyphenols may be attributed to their hydrogen donor ability to block free radical chain reactions in the oxidation process and thereby convert them into stable end product (Qin et al., 2013). Their antioxidant activities are mainly due to their radical scavenging activity, metal binding and reducing power (Naveena et al., 2008 a,b; Selani et al., 2011; Mahmmod, 2014).

\section{Microbial Content of Breast Meat}

The microbial content of breast meat in broilers fed diet supplemented with probiotic and pomegranate peel-, grape seed- and olive leaf-extracts was given in Table 3 .

Feeding P, OLE200, PPE100 and PPE200 diets significantly decreased total aerobe bacteria content of breast meat at $0^{\text {th }}$ and $7^{\text {th }}$ days compared to the other diets $(\mathrm{P}<0.001)$. Furthermore, total aerobe bacteria content of breast meat at $14^{\text {th }}$ day was significantly reduced by all dietary treatments compared to the CONT $\operatorname{diet}(\mathrm{P}<0.001)$.
The finding related to the microbial content of breast of broiler is in agreement with the results of Mahajan et al. (2000a) pointed out that dietary supplementation of probiotic significantly decreased total aerobic bacteria counts of breast meat of broilers. Bhaskar Reddy et al. (2013) found that the addition of grape seed extract significantly reduced the total aerobic psychrophilic bacteria count in restructured mutton slices during refrigerated storage.

The coliform bacteria content of breast meat at $0^{\text {th }}$ day was not found significantly. On the other hand, all dietary treatments significantly reduced the coliform bacteria content of breast meat at $7^{\text {th }}$ and $14^{\text {th }}$ days $(\mathrm{P}<0.001)$.

The P, OLE200, PPE100 and PPE200 diets significantly reduced lactic acid bacteria content of breast meat at $0^{\text {th }}, 7^{\text {th }}$ and $14^{\text {th }}$ days compared to the CONT diet $(\mathrm{P}<0.001)$. This finding concurs with the results of Aksu et al. (2005) reported that feeding the probiotic at the level of $0.2 \%$ significantly reduced total aerobic psychrophilic bacteria count and lactic acid bacteria count of breast meat compared to those of broilers fed the CONT diet.

This situation might be derived from the prevention of the growth of pathogenic microorganisms of probiotic bacteria by its multiplying in the mucus of the intestinal tract of broilers. 
Table 4 The $\mathrm{pH}$ values of breast meat in broilers fed diet supplemented with probiotic and pomegranate peel-, grape seed- and olive leaf-extracts

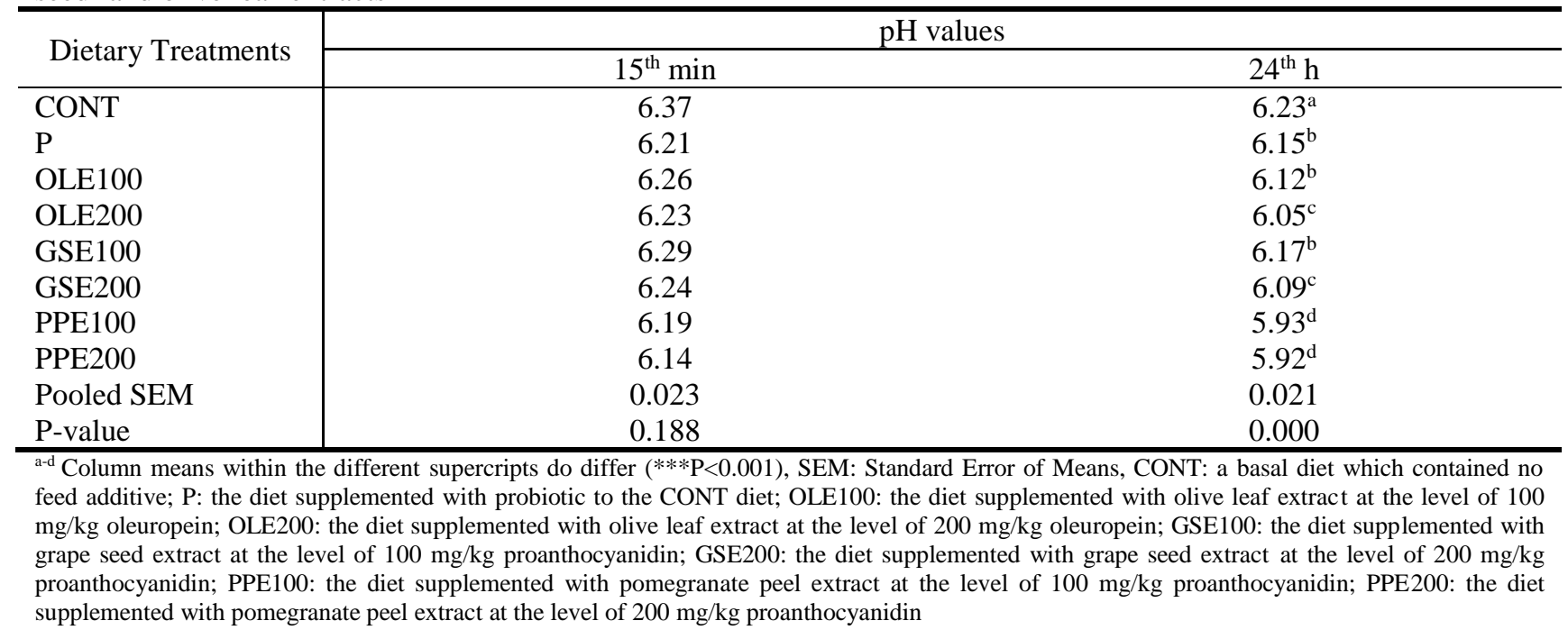

Table 5 The water holding capacity, drip loss and cooking loss of breast meat in broilers fed diets supplemented with probiotic and pomegranate peel-, grape seed- and olive leaf-extracts

\begin{tabular}{l|cccc}
\hline \multicolumn{1}{c}{ Dietary Treatments } & Water holding capacity & Drip loss $\left(3^{\mathrm{th}} \mathrm{d}\right)$ & Drip loss $\left(7^{\mathrm{th}} \mathrm{d}\right)$ & Cooking loss \\
\hline CONT & $24.56^{\mathrm{b}}$ & $1.90^{\mathrm{b}}$ & $2.28^{\mathrm{a}}$ & $20.46^{\mathrm{b}}$ \\
P & $24.82^{\mathrm{ab}}$ & $1.83^{\mathrm{c}}$ & $2.07^{\mathrm{b}}$ & $18.66^{\mathrm{d}}$ \\
OLE100 & $24.81^{\mathrm{ab}}$ & $1.92^{\mathrm{b}}$ & $2.31^{\mathrm{a}}$ & $19.13^{\mathrm{c}}$ \\
OLE200 & $24.86^{\mathrm{ab}}$ & $1.74^{\mathrm{d}}$ & $2.01^{\mathrm{b}}$ & $18.57^{\mathrm{d}}$ \\
GSE100 & $24.49^{\mathrm{b}}$ & $1.97^{\mathrm{b}}$ & $2.33^{\mathrm{a}}$ & $19.66^{\mathrm{c}}$ \\
GSE200 & $23.79^{\mathrm{c}}$ & $2.18^{\mathrm{a}}$ & $2.35^{\mathrm{a}}$ & $21.24^{\mathrm{a}}$ \\
PPE100 & $24.95^{\mathrm{a}}$ & $1.51^{\mathrm{e}}$ & $1.81^{\mathrm{c}}$ & $18.46^{\mathrm{d}}$ \\
PPE200 & $25.06^{\mathrm{a}}$ & $1.31^{\mathrm{f}}$ & $1.71^{\mathrm{d}}$ & $17.88^{\mathrm{e}}$ \\
Pooled SEM & 0.130 & 0.058 & 0.072 & 0.350 \\
P-value & 0.008 & 0.003 & 0.006 & 0.003 \\
\hline
\end{tabular}

${ }^{\mathrm{a}-\mathrm{f}}$ Column means within the different supercripts do differ $(* * \mathrm{P}<0.01)$, SEM: Standard Error of Means, CONT: a basal diet which contained no feed additive; P: the diet supplemented with probiotic to the CONT diet; OLE100: the diet supplemented with olive leaf extract at the level of $100 \mathrm{mg} / \mathrm{kg}$ oleuropein; OLE200: the diet supplemented with olive leaf extract at the level of $200 \mathrm{mg} / \mathrm{kg}$ oleuropein; GSE100: the diet supplemented with grape seed extract at the level of $100 \mathrm{mg} / \mathrm{kg}$ proanthocyanidin; GSE200: the diet supplemented with grape seed extract at the level of $200 \mathrm{mg} / \mathrm{kg}$ proanthocyanidin; PPE100: the diet supplemented with pomegranate peel extract at the level of $100 \mathrm{mg} / \mathrm{kg}$ proanthocyanidin; PPE200: the diet supplemented with pomegranate peel extract at the level of $200 \mathrm{mg} / \mathrm{kg}$ proanthocyanidin

\section{Meat Quality Parameters}

$p H$ values: The $\mathrm{pH}$ values of breast meat in broilers fed diets supplemented with probiotic and pomegranate peel-, grape seed- and olive leaf-extracts are given in Table 4.

As shown in Table 4, dietary treatments did not influence $\mathrm{pH}$ of breast meat of broilers at the first $15 \mathrm{~min}$. On the other hand, $\mathrm{pH}$ value of breast meat of broilers at 24 th $\mathrm{h}$ post-mortem was significantly decreased by feeding diets supplemented with probiotic and pomegranate-, grape seed- and olive leaf-extracts $(\mathrm{P}<0.001)$.

The reduction in $\mathrm{pH}$ attributes to depletion of muscle glycogen stores due to their conversion to lactic acid at post-mortem period (Kim et al., 2016).

This result is in agreement with the finding of $\mathrm{Al}$ Qazzez et al. (2014) who reported that the pomegranate peel extract significantly reduced $\mathrm{pH}$ value of minced frozen chicken meat. Kaur et al. (2015) also pointed out that the $\mathrm{pH}$ value of chicken nuggets prepared with grape seed extract supplementation was significantly lower than the control diet. In addition, there is a study associated with the reducing effect of olive leaves supplementation at 5 and $10 \mathrm{~g} / \mathrm{kg}$ level to broiler diets on the $\mathrm{pH}$ values of the thighs and drumsticks compared to the control diet (Marangoni et al., 2017). Abdulla et al. (2017) reported that broiler chickens fed the diet supplemented with probiotic had the lowest $\mathrm{pH}$ value compared to the control diet. The low $\mathrm{pH}$ value in breast meat of broilers fed the diets supplemented with OLE, GSE and PPE may be derived from the preventing effect of antimicrobial bioactive compounds found in these extracts on the proliferation and the growth of bacteria that metabolize nitrogen compounds (Zhang et al., 2016). In contrast, Brannan (2009) and Selani et al. (2011) found no differences between the group supplemented with grape seed extracts and the control group in terms of $\mathrm{pH}$ value of chicken meat. Likewise, Kim et al. (2016) pointed out that there are no differences between $\mathrm{pH}$ values of the breast meat of chickens fed the control diet and diet supplemented with probiotic.

Water holding capacity, drip loss and cooking loss: The water holding capacity, drip loss at $3^{\text {th }}$ and $7^{\text {th }}$ days and cooking loss of breast meat in broilers fed diets supplemented with probiotic and pomegranate peel-, grape seed- and olive leaf-extracts are shown in Table 5. 
As indicated in Table 5, the PPE100 and PPE200 diets significantly increased the water holding capacity of breast meat at $42 \mathrm{~d}$ compared to those of broilers fed the CONT, GSE100 and GSE200 diets $(\mathrm{P}<0.01)$. The water holding capacity of breast meat of broilers fed the P diet was statistically similar to that of broilers fed the CONT diet. This finding concurs with the result of Pelicano et al. (2003) who reported that there were no differences in water holding capacity of breast meat of broilers fed the control diet and diet supplemented with probiotic. Morever, Marangoni et al. (2017) reported that the water holding capacity of chicken thigh and drumsticks meat was significantly increased by the olive leaves supplementation compared to the control diet.

On the contrary, Al-Qazzez et al. (2014) found that the pomegranate peel extract significantly decreased water holding capacity of minced frozen chicken meat. The PPE100 and PPE200 diets may have been improved the meat quality due to the higher water holding capacity such as greater juiciness, more palatability and desirable sensory (Huallanco 2004; Marangoni et al., 2017). As a result of this, the phenol may be absorbed on the protein surface and interact with protein in reversible and irreversible ways that caused to variation in charge distribution. The alteration of charge distribution due to a polyphenol-protein complex may have lead to the increase of water holding capacity by the supplementation of pomegranate peel extract (Hayes et al., 2010).

As shown in Table 5, all dietary treatments except GSE200 diet significantly decreased the drip loss of broiler breast meat at $3^{\text {th }}(\mathrm{P}<0.01)$ day of the storage compared to the CONT. The P, OLE200, PPE100 and PPE200 diets significantly decreased the drip loss of breast meat at $7^{\text {th }}$ day compared to those of broilers fed the CONT, OLE100, GSE100 and GSE200 diets $(\mathrm{P}<0.01)$. This result concurs with the finding of $\mathrm{Al}-$ Qazzez et al. (2014) who reported that the pomegranate peel extract supplementation at $0.5,1.0$ and $1.5 \%$ levels significantly reduced the drip loss of minced frozen chicken meat. The low drip loss observed in chickens fed diet supplemented with probiotic supported the results of Abdulla et al. (2017) who showed reduction in drip loss in breast meat of broilers fed probiotic. Probiotic and phenolic compounds in OLE200, PPE100 and PPE200 diets stabilized cell integrity and increased the ability of meat to retain sarcoplasmic compounds (Mitsumoto et al., 2005). As a result of this, loss of water soluble nutrients due to drip loss was significantly decreased (Mahmmod 2014; Abdulla et al., 2017).

Table 5 indicated that all dietary treatments except GSE200 diet significantly reduced the cooking loss of chicken breast meat at $42 \mathrm{~d}$ compared to the CONT diet $(\mathrm{P}<0.01)$. This finding is in agreement with the result of Mahmmod (2014) who reported that the olive leaf extract at 2 and $4 \%$ significantly reduced cooking loss of lamb meat stored at $+4^{\circ} \mathrm{C}$ for seven days. Likewise, Al-Qazzez et al. (2014) reported that the pomegranate peel extract supplementation significantly decreased the cooking loos of minced frozen chicken meat. It may be derived from the increase of the water binding capacity of pomegranate peel extract that enhanced the ability of meat to retain water and reduced the cooking loss during cooking (Mahmmod, 2014). Likewise, the study finding of
Abdulla et al. (2017) indicated that the dietary supplementation of sole probiotic led to the lowest cooking loss in breast meat of broiler chickens. On the contrary, Kurt (2015) pointed out that the grape seed powder at $0.5,1$ and $2 \%$ concentrations did not significantly influenced the cooking loss of beef patties compared to the control group. Kim et al. (2016) also showed that the dietary probiotic supplementation had no any significant effect on cooking loss in broiler breast meat.

\section{Conclusion}

It was concluded that probiotic, olive leaf- and pomegranate peel- extracts have potential to be used as natural antimicrobial feed additives in terms of their lipid oxidation, microbial content and quality parameters of broiler meat.

\section{References}

Abdulla NR, Zamri ANM, Sabow AB, Kareem KY, Nurhazirah S, Ling FH, Sazili AQ, Loh TC. 2017. Physico-chemical properties of breast muscle in broiler chickens fed probiotics, antiobiotics or antibiotic-probiotic mix. J Appl Anim Res., 45 (1): 64-70.

Ahmed ST, Islam MM, Bostami AB, Mun HS, Kim YJ, Yang CJ. 2015. Meat composition, fatty acid profile and oxidative stability of meat from broilers supplemented with pomegranate (Punica granatum L.) by-products. Food Chem., 188: 481-488.

Aksu MI, Karaoglu M, Esenbuga N, Kaya M, Macit M, Ockerman, HW. 2005. Effect of a dietary probiotic on some quality characteristics of raw broiler drumsticks and breast meat. J Muscle Foods, 16: 306-312.

Al-Qazzez MF. 2014. The effect of using pomegranate peel extract on the quality and chemical characteristics for minced frozen spent chicken meat. Diyala Agricul Sci J., 6 (1): $1-10$.

AOAC. 2007. Association of Official Analytical Chemists. 18 th. Edition, W.D.C. USA.

Bate-Smith EC. 1975. Phytochemistry of proantocyanidins. Phytochem., 14: 1107-1113. doi:10.1.1016/00319422(75)85197-1.

Baumgart J, Firnhaber J, Spcher G. 1993. Mikrobiologische untersuchung von lebensmitteln behr's verlag. Hamburg, Germany.

Baycin D, Altiok E, Ulku S, Bayraktar O. 2007. Adsorption of olive leaf (Olea europaea L.) antioxidants on silk fibroin. J Agric and Food Chem., 55: 1227-1236.

Benavente-Garcia O, Castillo J, Lorento J, Ortuno A, Del Rio JA. 2000. Antioxidant activity of phenolics extracted from Olea europaea L. leaves. Food Chem., 68: 457-462.

Bhaskar Reddy GV, Sen AR, Nair PN, Sudhakar Reddy K, Kondal Reddy K, Kondaiah N. 2013. Effects of grape seed extract on the oxidative and microbial stability of restructured mutton slides. Meat Sci., 288-294.

Bond JJ, Warner RD. 2007. Ion distribution and protein proteolysis affect water holding capacity of Longissimus thoracis et lumborum in meat of lamb subjected to antemortem exercise. Meat Sci., 75: 406-414.

Botsoglou NA, Florou-Paneri P, Christaki E, Fletouris DJ, Spais AB. 2002. Effect of dietary oregano essential oil on performance of chickens and on iron-induced lipid oxidation of breast, thigh and abdominal fat tissues. Br Poult Sci., 43(2): 223-230 
Brannan RG. 2009. Effect of grape seed extract on descriptive sensory analysis of ground chicken during refrigerated storage. Meat Sci., 81: 589-595.

Castellini C, Mugnai C, Dal Bosco A. 2002. Effect of organic production system on broiler carcass and meat quality. Meat Sci., 60: 219-225.

Chiang W, Booren A, Strasburg G. 2008. The effect of heat stress on thyroid hormone response and meat quality in turkeys of two genetic lines. Meat Sci., 80: 615-622.

Duncan DB. 1955. Multiple Range Test and Multiple F Tests. Biometrics. 11: 1-42.

Farahat MH, Abdallah FM, Ali HA, Hernandez-Santana A. 2016. Effect of dietary supplementation of grape seed extract on the growth performance, lipid profile, antioxidant status and immune reponse of broiler chickens. Animal, doi: 10.1017/S1751731116002251. 1-7.

Govaris A, Botsoglou E, Moulas A, Botsoglou N. 2010. Effect of dietary olive leaves and rosemary on microbial growth and lipid oxidation of turkey breast during refrigerated storage. South Afr J Anim Sci. 40 (2): 145-155.

Hayes JE, Stepanyan V, Allen P, O'Grady MN, Kerry JP. 2010. Effect of lutein, sesamol, ellagic acid and olive leaf extract on the quality and shelf-life stability of packaged raw minced beef patties. Meat Sci., 84: 613-620.

Huallanco MBA. 2004. Aplicaçâo de um sistema de classicaçâo de carcaças e cortes e efeito pós abate da qualidade de cores de frando criados no sistema alternativo. Piracicaka: Escola superior de Agricultura Luiz de Queiroz, MSc thesis.

Kanatt SR, Chander R, Sharma A. 2010. Antioxidant and antimicrobial activity of pomegranate peel extract improves the shelf life of chicken products. Int $\mathrm{J}$ Food Sci and Technol., 45(2): 216-222.

Khaksefidi A, Rahimi Sh. 2005. Effect of probiotic inclusion in the diet of broiler chickens on performance, feed efficiency and carcass quality. Asian-Austr J Anim Sci., 18 (8): 1153 1156.

Kaur S, Kumar S, Bhat ZF, Kumar A. 2015. Effect of pomegranate seed powder, grape seed extract and tomato powder on the quality characterisitics of chicken nuggets. Nutr and Food Sci., 6 (4): 583-594.

Kim HW, Yan FF, Hu JY, Cheng HW, Kim YHB. 2016. Effects of probiotics feeding on meat quality of chicken breast during postmortem storage. Poult Sci., 95: 1457-1464.

Kurt Ş. 2015. The effects of grape seed flour on the raw and cooked beef patties quality. Vet ir zootechn (Vet Med Zoot). T., 69 (91): 34-37.

Lu QP, Wen J, Zhang HF. 2007. Effect of chronic heat exposure on fat deposition and meat quality in two genetic types of chicken. Poult Sci., 86: 1059-1064.

Mahajan P, Sahoo J, Panda PC. 2000a. Effect of probiotic (Lacto-Sacc) feeding and season on poultry meat quality. Indian Poult. Sci. Assoc., 35: 297-301.

Mahmmod AB. 2014. Study the effects of olive leaf extract on physio-chemical and sensory traits of mutton meat at low temperature. Assiut Vet Med J., 60 (143): 1-7.
Marangoni C, Cichoski AJ, Barin JS. 2017. Effect of olive leaves on the quality of chicken meat during frozen storage. Int Food Res J., 24 (1): 164-172.

Mielnik MB, Olsen E, Vogt G, Adeline D, Skrede G. 2006. Grape seed extract as antioxidant in cooked cold stored turkey meat. LWT Food Sci and Technol., 39: 191-198.

Mitchaothai J, Yuangklang C, Wittayakun S, Vasupen K, Wongsutthavas S, Srenaul P, Hovenier R, Everts H, Beynen AC. 2006. Effect of dietary fat type on meat quality and fatty acid composition of various tissues in growingfinishing swine. Meat Sci., 105: 1067-1075.

Mitsumoto M, O'Grady MN, Kerry JP, Buckley DJ. 2005. Addition of tea catechins and vitamin $\mathrm{C}$ on sensory evaluation, colour and lipid stability during chilled storage in cooed or raw beef and chicken patties. Meat Sci., 69: 773779 .

Naveena BM, Sen AR, Vaithiyanathan S, Babji Y, Kandaiah N. 2008a. Comparative efficacy of pomegranate juice, pomegranate rind powder extract and BHT as antioxidants in cooked chicken patties. Meat Sci., 80: 1304-1308.

Naveena BM, Sen AR, Kingsyl RP, Singh DB, Kondaiah N. 2008b. Antioxidant activity of pomegranate rind powder extract in cooked chicken patties. Int $\mathrm{J}$ Food Sci and Technol., 43 (10): 1807-1812.

Qin YY, Zhang ZH, Li L, Xiong W, Shi JY, Zhao TR, Fan J. 2013. Antioxidant effect of pomegranate rind powder extract, pomegranate juice and pomegranate seed powder extract as antioxidants in raw ground pork meat. Food Sci. Biotechnol. 22 (4): 1063-1069.

Pelicano ERL, Souza PA de, Souza HBA de, Oba A, Norkus EA, Kodawara LM, Lima TMA de. 2003. Effect of different probiotics on broiler carcass and meat quality. Rev Brasil de Ciencia Avicola, 5 (3): 207-214.

Saleh H, Golian A, Kermanshahi H, Farhosh R, Abrishamchi R. 2015. Evaluation of $\alpha$-tocopherol actetate, peel and extract pomegranate antioxidative potential in diet contained fish oil on meat quality broiler chickens. Iranian J Anim Sci Res., 7 (3): 305-317.

Saleh H, Golian A, Kermanshahi H, Mirakzchi MT. 2017. Effects of dietary $\alpha$-tocopherol acetate, pomegranate peel and pomegranate peel extract on phenolic content, fatty aid composition and meat quality of broiler chickens. J Appl Anim Res., 45 (1): 629-636.

Selani MM, Conteras-Castillo CJ, Shirahigue LD, Gallo CR, Plata-Ovicdo M, Montes-Villanveva ND. 2011. Wine industry residues extracts as natural antioxidants in raw and cooked chicken meat during frozen storage. Meat Sci., 88: 397-403.

Turgut SS, Işıkçı F, Soyer A. 2017. Antioxidant activity of pomegranate peel extract on lipid and protein oxidation in beef meatballs during frozen storage. Meat Sci., 129: 111119.

SPSSWIN. 2007. SPSS for Windows 6.1.4. SPSSWIN, Istanbul, Turkey

Zhang H, Wu J, Guo X. 2016. Effects of antimicrobial and antioxidant activities of spice extracts on raw chicken meat quality. Food Sci and Human Wellness, 5: 39-48. 